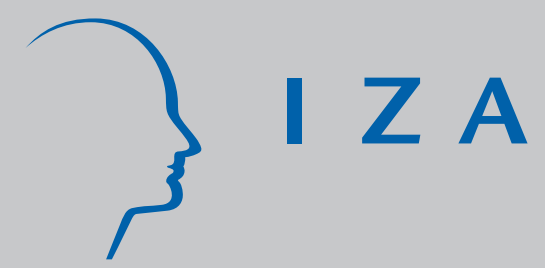

IZA DP No. 7093

The Impact of Educational Mismatch on Firm Productivity: Evidence from Linked Panel Data

Stephan Kampelmann

François Rycx

December 2012

Forschungsinstitut zur Zukunft der Arbeit Institute for the Study of Labor 


\title{
The Impact of Educational Mismatch on Firm Productivity: Evidence from Linked Panel Data
}

\author{
Stephan Kampelmann \\ Université Libre de Bruxelles, SBS-EM (CEB and DULBEA) \\ François Rycx \\ Université Libre de Bruxelles, SBS-EM (CEB and DULBEA) \\ and IZA
}

\section{Discussion Paper No. 7093 \\ December 2012}

\author{
IZA \\ P.O. Box 7240 \\ 53072 Bonn \\ Germany \\ Phone: +49-228-3894-0 \\ Fax: +49-228-3894-180 \\ E-mail: iza@iza.org
}

\begin{abstract}
Any opinions expressed here are those of the author(s) and not those of IZA. Research published in this series may include views on policy, but the institute itself takes no institutional policy positions. The IZA research network is committed to the IZA Guiding Principles of Research Integrity.

The Institute for the Study of Labor (IZA) in Bonn is a local and virtual international research center and a place of communication between science, politics and business. IZA is an independent nonprofit organization supported by Deutsche Post Foundation. The center is associated with the University of Bonn and offers a stimulating research environment through its international network, workshops and conferences, data service, project support, research visits and doctoral program. IZA engages in (i) original and internationally competitive research in all fields of labor economics, (ii) development of policy concepts, and (iii) dissemination of research results and concepts to the interested public.
\end{abstract}

IZA Discussion Papers often represent preliminary work and are circulated to encourage discussion. Citation of such a paper should account for its provisional character. A revised version may be available directly from the author. 
IZA Discussion Paper No. 7093

December 2012

\section{ABSTRACT}

\section{The Impact of Educational Mismatch on Firm Productivity: Evidence from Linked Panel Data}

We provide first evidence regarding the direct impact of educational mismatch on firm productivity. To do so, we rely on representative linked employer-employee panel data for Belgium covering the period 1999-2006. Controlling for simultaneity issues, time-invariant unobserved workplace characteristics, cohort effects and dynamics in the adjustment process of productivity, we find that: i) a higher level of required education exerts a significantly positive influence on firm productivity, ii) additional years of over-education (both among young and older workers) are beneficial for firm productivity, and iii) additional years of under-education (among young workers) are detrimental for firm productivity.

JEL Classification: $\quad 121, \mathrm{~J} 24$

Keywords: educational mismatch, productivity, linked panel data, GMM

Corresponding author:

François Rycx

SBS-EM (CEB, DULBEA)

Université Libre de Bruxelles

CP 114/02, Avenue F.D. Roosevelt, 50

B-1050 Brussels

Belgium

E-mail: frycx@ulb.ac.be 


\section{Introduction}

Educational mismatch (or simply over- and under-education) refers to the difference between the worker's attained level of education and the education required in the job. This important phenomenon, first highlighted by Freeman (1976), has been extensively studied, especially since the late 1980s, in order to evaluate the consequences of the continued expansion of participation rates in higher education that are observed in developed economies (McGuinness, 2006). For many decades, advanced economies have implemented policies aiming to increase the level of education of their labour force. The 'European strategic framework on education and training', for instance, aims to raise the share of people aged between 30 and 34 with tertiary education to 40 percent on average in the European Union by 2020. This strategy implicitly assumes that there is excess demand for tertiary education or that firms employing more educated workers will improve their production techniques to take advantage of those additional skills (McGuinness, 2006). However, if these assumptions are not satisfied then workers with tertiary education may end up in jobs for which they are overeducated. Moreover, in periods of excess labour supply, there may be some 'crowding out', i.e. a process by which workers with tertiary education take up jobs that could be occupied by less educated ones.

The proportion of over-educated workers in the OECD area stands today at around 25 percent and about 1 out of 5 workers is recorded as under-educated (OECD, 2011). Given the magnitude of these figures, "many observers point to: i) the failure of the education system in providing youth with the skills required at work, and ii) the inability of labour markets to sort many workers to suitable jobs” (OECD, 2011, p. 193). Moreover, McGuinness (2006) emphasizes that educational mismatch may be costly for the economy as a whole (e.g. a waste in tax revenues due to the financing of excessive levels of education), for firms (e.g. a loss in efficiency if over-educated workers are less productive than their adequately educated colleagues) but also for individuals (e.g. over-educated workers may earn less than their former classmates doing jobs that match their education).

What do we know from existing research? The incidence and earnings effects of educational mismatch are well documented in the economic literature and findings are quite consistent (Hartog, 2000, Leuven and Oosterbeek, 2011). They notably show that, in a given job with a specific level of required education, over- (under-) educated workers earn more (less) than those who have just the required education for the job (Battu et al., 1999, Dolton and Vignoles, 2000, Frenette, 2004, McGuinness, 2003, van der Meer, 2006). In contrast, the 
evidence regarding the impact of over- and under-education on firm productivity is mixed, indirect and subject to various potential biases. A first strand of the literature relies on human capital theory to infer the consequences of educational mismatch on productivity. As a result, productivity effects of over- and under-education are deduced from the latter's impact on wages. Other studies examine how educational mismatch influences job satisfaction and other correlates of workers' productivity (such as absenteeism, shirking, turnover or training).

The "human capital” and "job satisfaction" approaches lead to quite different conclusions. While the former suggests that over- (under-) educated workers are more (less) productive than their adequately educated colleagues in similar jobs, the latter provides ambiguous predictions. Both approaches also suffer from important methodological limitations. Indeed, the relationship between education, wages and productivity is likely to be much more complex than that put forward by standard human capital theory. In addition, empirical results suggest that the correlation between job satisfaction and job performance reaches at most 30 percent (Judge et al., 2001). It may thus be quite misleading to focus solely on job satisfaction to estimate the productivity effects of educational mismatch. Finally, overeducation probably affects productivity through other channels than job satisfaction (and correlated workers' attitudes and behaviours). For instance, in line with human capital theory, it could be argued that the (possible) negative effect on firm productivity of over-educated workers through their (potential) lower degree of job satisfaction could (at least partially) be compensated by their additional skills and capabilities acquired in school.

Given the inconclusiveness and shortcomings of the existing literature, there is an obvious need for further research. To paraphrase Hartog (2000), it would be highly informative if we knew the effect of over- and under-education on productivity, rather than on wages, job satisfaction and related workers' attitudes and behaviours (such as absenteeism, shirking, turnover or training). This is the purpose of the present paper. We rely on an ORU (Over-, Required and Under-education) specification that has been aggregated at the level of the firm, we use the average firm-level value added per worker as dependent variable and we apply the dynamic system GMM estimator to representative linked employer-employee panel data for Belgium covering the years 1999-2006. We thus examine how mean years of overand under-education within firms affect the productivity of the latter, conditional on mean years of required education. Moreover, as the relationship between educational mismatch and productivity is likely to be more pronounced for recent labour market entrants (Verhaest and Omey, 2009), we also add to the literature by investigating whether the effects of educational mismatch on firm productivity vary according to the age of over- and under-educated 
workers. Finally, the richness of our data allows us to control for important econometric issues that are often neglected in other studies, such as the potential endogeneity of educational mismatch, the existence of firm unobserved fixed effects, cohort effects and the state dependence of firm productivity.

The remainder of this paper is organized as follows. A review of the literature is presented in the next section. Sections 3 and 4 respectively describe our methodology and data set. The impact of educational mismatch on firm productivity is analysed in section 5 . The last section discusses the results and concludes.

\section{Background}

Two types of approaches have been considered in the literature to examine the impact of educational mismatch on productivity in a microeconomic framework. The first one relies on standard human capital theory (Becker, 1964). According to this theory, i) education (as well as formal training and informal work experience) develops skills that make workers more productive and ii) wage differentials reflect differences in productivity. Consequently, the impact of over- and under-education on productivity might be inferred from the latter's effect on wages. This strategy has been followed for instance by Rumberger (1987). His results, based on U.S. cross-sectional data for the late 1960s and 1970s, show that the wage differential for a year of over-education is positive but lower than that for a year of required education. Therefore, he suggests that: "additional schooling is not completely unproductive, but simply that jobs constrain the ability of workers to fully utilize the skills and capabilities they acquire in school” (Rumberger, 1987, p. 46). Other studies regarding the wage effects of educational mismatch also highlight that, in a given job with a specific level of required education, over- (under-) educated workers earn more (less) than those who have just the required education for the job (Battu et al., 1999, Dolton and Vignoles, 2000, Duncan and Hoffman, 1981, Groot, 1996, Groot and Maassen van den Brink, 2000, Sicherman, 1991, van der Meer, 2006). Although part of this premium (penalty) may be explained by workers' unobserved heterogeneity (Bauer, 2002, Chevalier, 2003, Dolton and Silles, 2008, Frenette, 2004, Lamo and Messina, 2010, McGuinness, 2003, McGuinness and Sloane, 2011), current evidence on the basis of human capital theory thus suggests that over- (under-) education increases (reduces) workers’ productivity. ${ }^{1}$

\footnotetext{
${ }^{1}$ Further results, based on the specification introduced by Verdugo and Verdugo (1989), show that, for a given attained education, over- (under-) educated workers are paid less (more) than adequately educated workers
} 
Another strand of the literature examines the impact of educational mismatch on job satisfaction and other correlates of workers' productivity (such as absenteeism, shirking, turnover or training). The standard hypothesis is that over-educated workers, as a result of frustration, are less satisfied, have more health problems and higher rates of shirking, absenteeism and turnover than their adequately educated colleagues. Given that all these factors are likely to have a negative impact on productivity, the assumption is that firms are reluctant to hire over-educated applicants (Büchel, 2002). The relationship between job satisfaction and job performance has been extensively studied by industrial psychologists. Their results indicate that the satisfaction-performance correlation is positive but not strong: close to 0.30 according to the meta-analysis of Judge et al. (2001) and around 0.17 according to that of Iaffaldano and Muchinsky (1985). Under the hypothesis that over-education leads to less job satisfaction, this finding suggests that educational mismatch may hurt productivity but to a limited extent. Empirical studies investigating the impact of ORU on job satisfaction (and other correlates of workers' productivity) provide mixed results. ${ }^{2}$ Hersch (1991) for instance finds, with cross-sectional data collected in the Eugene (Oregon area, U.S.) in 1986, that over-educated workers (both male and female) and female under-educated workers are less satisfied than their adequately educated colleagues in similar jobs. In addition, his results show that male over-educated workers are more likely to quit their job and that over-educated workers (both male and female) benefit less from training. The study of Tsang et al. (1991), based on U.S. cross-sectional data from the late 1960's and 1970's, also supports the hypothesis that male workers who are (highly) over-educated tend to be less satisfied and more inclined to quit their job. Yet, unlike Hersch (1991), Tsang et al. (1991) report no significant effect of over-education on job satisfaction for female workers. Relying on West-

(Hartog, 2000, McGuinness, 2006). Following human capital theory, this would imply that workers, with a given education, who get a job requiring less (more) education than they have, will be less (more) productive than those in a job just matching their education. It is also worthwhile to note that in the career mobility model developed by Sicherman and Galor (1990), over-education is part of a long-run strategy. The point is that overeducated people accept a wage penalty in the short run (with respect to adequately educated workers with the same attained education) because they anticipate that this penalty will be compensated by higher future wage growth. The evidence regarding the validity of this model is mixed (see e.g. Büchel and Mertens, 2004, Hersch, 1991, Korpi and Tählin, 2009, Robst, 1995, Sicherman, 1991, Sicherman and Galor, 1990).

${ }^{2}$ Findings conditional on attained education are more consistent. They generally indicate that over-educated workers have a lower level of job satisfaction, receive less training and are more likely to quit their jobs than their adequately educated former classmates, i.e. individuals with the same attained education (Ahn et al., 2001, Allen and van der Velden, 2001, Battu et al., 2000, Büchel and Mertens, 2004, Feldman and Turnley, 1995, Sicherman, 1991, Tsang, 1987, van Smoorenburg and van der Velden, 2000, Verhaest and Omey, 2006, Vieira, 2005). These results suggest that over-education is likely to induce negative productivity costs for firms (due to higher turnover rates) and the overall economy (due to a lower level of job satisfaction and less training participation). Results regarding the effects of under-education on job satisfaction, turnover and training, conditional on attained education, are less numerous and often insignificant (see e.g. Allen and van der Velden, 2001, Verhofstadt and Omey, 2003). 
German cross-sectional and longitudinal data covering the period 1984 to 1995, Büchel (2002) finds no significant relation between over-education and job satisfaction. ${ }^{3}$ He also shows that over-educated workers are healthier, more strongly work- and career-minded, more likely to participate in on-the-job training and to have more years of tenure with the same firm than their adequately educated colleagues in jobs with similar requirements. ${ }^{4}$ Using a survey of school leavers in Flanders (Belgium) that was conducted in 1999 and 2002, Verhaest and Omey (2006) support the standard hypothesis that over-educated workers have a higher turnover rate than those who have just the required education for the job. However, they find no robust results regarding the impact of over-education on job satisfaction and training participation. Moreover, their results for under-educated workers are generally unclear. In a more recent exercise, Verhaest and Omey (2009) apply a shadow price approach to study the relation between over-education and job satisfaction. Their results based on an extended version of their survey of Flemish school leavers (interviewed in 1999 and the early 2000s) show that over-educated workers are significantly less satisfied than their adequately educated colleagues in similar jobs, even after controlling for individual fixed effects. ${ }^{5}$ They also highlight that the wage premium earned by over-educated workers with regard to those who have just the required education for the job only partially compensates for their lower utility (i.e. satisfaction). Finally, their results indicate that the negative consequence of overeducation on satisfaction diminishes with years of work experience. In contrast to the above mentioned literature, Tsang (1987) does not only investigate the effect of over-education on job satisfaction but he also constructs a firm-level job-satisfaction index and estimates the latter's impact on firm productivity using a Cobb-Douglas production function. His results, based on individual- and firm-level data from twenty-two U.S. Bell companies for the period 1981-1982, indicate that over-education is significantly and negatively related to job satisfaction, which is in turn positively and significantly related to output. They thus suggest that over-education is detrimental for firm productivity in the telephone industry.

Overall, it turns out that the two approaches developed in the literature to uncover productivity effects of educational mismatch lead to different conclusions. Earnings effects of over- (under-) education suggest on the basis of human capital theory that over- (under-) educated workers are at least slightly more (less) productive than those with the required

\footnotetext{
${ }^{3}$ This result is in line with some earlier studies including e.g. Groot and Maassen van den Brink (2000), Kahn and Morrow (1991) and King and Hautaluoma (1987).

${ }^{4}$ The effect of under-education is neither investigated by Tsang et al. (1991) nor by Büchel (2002).

${ }^{5}$ Under-educated workers are also found to be less satisfied than those who have just the required education for the job when regressions are estimated by OLS. Yet, the difference in job satisfaction between these groups of workers becomes insignificant when a random effects model is applied.
} 
education for the job. In contrast, studies focusing on job satisfaction (and other correlates of workers' productivity) provide inconsistent predictions from a firm's point of view. This is due to the fact that the consequences of educational mismatch on job satisfaction are still unsettled when using an ORU specification (which is obviously the most appropriate when considering the firm perspective).

Both approaches also suffer from important methodological limitations. The human capital approach is based on the hypothesis that both human capital and earnings are directly proportional to individual productivity on the job (Rumberger, 1987). However, the relationship between human capital, wages and productivity is likely to be more complex. On the one hand, human capital may only have a limited impact on productivity. Signaling theory (Spence, 1973, 1979), for instance, puts forward that a worker's productivity is a sort of intrinsic quality that does not really depend on education but rather on other factors such as family background, individual history, innate quality or talent (Cahuc and Zylberberg, 2004, Riley, 2001). While signaling theory finds some empirical support (Groot and Oosterbeek, 1994), it is however unlikely to completely discount the role of human capital (Chevalier et al., 2004). On the other hand, wages may not only reflect marginal productivity. Indeed, noncompetitive models of wage determination (including collective bargaining, rent-sharing, search and recruiting frictions, discrimination or monopsony) find some support in the empirical literature (Bayard et al., 2003, Blanchflower and Bryson, 2010, du Caju et al., 2011, Manning, 2003, Martins, 2009, Mortensen, 2003, Rusinek and Rycx, 2012). Workers with identical productive characteristics thus not necessarily receive the same wages. ${ }^{6}$

The second approach, focusing on job satisfaction (and other correlates of workers' productivity), is also limited methodologically. A first point is that many studies investigate the direct impact of over-education on job satisfaction but neglect potential indirect effects (Verhaest and Omey, 2009). Typically, over-educated workers are found to earn more than those who have just the required education for the job. Given that job satisfaction depends positively on workers' wages, one should control for wages and more generally for any job characteristic related to satisfaction to compute the net effect of over-education on job satisfaction. Surprisingly, this is not always the case in the literature. It is also worthwhile to recall that the impact of job satisfaction on job performance is found to be modest (Judge et al., 2001). Therefore, even if it could be shown that over-educated workers are less satisfied

\footnotetext{
${ }^{6}$ Note that in most studies, estimating so-called human capital wage equations, “observable characteristics that are supposed to account for productivity differences typically explain no more than 30 percent of the variation in compensation across workers” (Mortensen, 2003, p. 1).
} 
with their jobs, the extent to which over-education affects firm productivity would remain unclear. ${ }^{7}$ Finally, it should be highlighted that educational mismatch may affect productivity through other channels than job satisfaction (and correlated workers' attitudes and behaviours). Indeed, in line with human capital theory, it could be argued that even if overeducated workers are less satisfied with their jobs, they may be more productive than their adequately educated colleagues in similar jobs simply because they have more years of education. To put it differently, a lower degree of job satisfaction might be compensated by additional skills and capabilities acquired in school so that the net effect of over-education on productivity might even be positive or simply non significant.

In sum, the evidence regarding the impact of over- and under-education on productivity is mixed, indirect and subject to various shortcomings. A decade ago, Hartog (2000) already emphasized that it would be highly informative if we knew the effect of over- and undereducation on productivity, rather than on wages, job satisfaction and related workers' attitudes and behaviours. Surprisingly, his statement is still valid. Therefore, in this paper we investigate the direct impact of ORU on a precise measure of firm productivity, namely the average value added per worker. We also examine whether the consequences of educational mismatch for firm productivity vary according to the age of over- and under-educated workers.

\section{Methodology}

Three different measures, based respectively on job analysis, worker self-assessment and realized matches, have been proposed in the literature to estimate the required education for a job and the incidence of educational mismatch. Each measure has its own advantages and weaknesses (for a discussion see e.g. Hartog, 2000). In this article, we use realized matches. So, the required education for a job is computed by taking the mode of workers' years of education $^{8}$ within each ISCO three-digit occupation (113 categories). A worker is then

\footnotetext{
${ }^{7}$ The only study that overcomes this problem is that of Tsang (1987). However, it dates back to the 1980s and covers only the U.S. telephone industry. In addition, it relies on quite a rough measure of productivity, namely firms' output, and no panel data techniques were applied.

${ }^{8}$ The workers' educational attainment is available in 7 categories in our data set. This information, reported by firms' human resources departments (on the basis of their registers), has been transformed in years of education. To do so, we applied the following rule: i) primary education or no degree: 6 years of education; ii) lower secondary education: 9 years of education; iii) general upper secondary education: 12 years of education; iv) technical, artistic and professional upper secondary education: 12 years of education; v) higher non-university education, short type: 14 years of education; vi) university and non-university education, long type: 16 years of education; vii) post-graduate education: 17 years of education.
} 
defined as over- (under-) educated if his attained years of education are higher (lower) than those required in his occupation.

To examine the impact of educational mismatch on firm productivity, we use an ORU specification that has been aggregated at the level of the firm. More precisely, we estimate the following firm-level productivity equation:

$$
\begin{aligned}
\ln V A_{-} \text {work }_{j, t}= & \beta_{0}+\beta_{1}\left(\ln V A_{-} \text {work }_{j, t-1}\right)+\beta_{2}\left(\frac{1}{m_{j, t}} \sum_{i=1}^{m_{j, t}} R E Q_{i, j, t}\right)+\beta_{3}\left(\frac{1}{m_{j, t}} \sum_{i=1}^{m_{j, t}} O V E R_{i, j, t}\right) \\
& +\beta_{4}\left(\frac{1}{m_{j, t}} \sum_{i=1}^{m_{j, t}} U N D E R_{i, j, t}\right)+X_{j, t} \beta_{5}+Z_{j, t} \beta_{6}+\gamma_{t}+v_{j, t}
\end{aligned}
$$

with :

a) VA_work $k_{j, t}$ the productivity of firm $j$ at year $t$, measured by the average value added per worker.

b) $m_{j, t}$ the number of workers employed in firm $j$ at year $t$.

c) $R E Q_{i, j, t}$ the required years of education for the job of worker $i$ in firm $j$ at year $t$, i.e. the mode of years of education in worker's $i$ occupation at the ISCO 3-digit level (across the entire economy) at time $t$.

d) $O_{V E R}, j, t=\left(\right.$ Attained_education $\left._{i, j, t}-R E Q_{i, j, t}\right)$ if $>0,0$ otherwise.

e) $U N D E R_{i, j, t}=\left(\right.$ Attained_education $\left._{i, j, t}-R E Q_{i, j, t}\right)$ if $<0,0$ otherwise.

f) Attained_education ${ }_{i, j, t}$ the number of years corresponding to the highest level of education attained by worker $i$ employed in firm $j$ at time $t$.

g) $X_{j, t}$ is a vector containing aggregated characteristics of workers, namely the share of the workforce that has at least 10 years of tenure, the fraction of workers respectively younger than 25 and older than 49 years, and the share of women, blue-collar and part-time workers.

h) $Z_{j, t}$ includes firm characteristics, namely the sectoral affiliation (8 dummies), age ${ }^{9}$ and size $^{10}$ (number of workers) of the firm, conditional dispersion in hourly wages ${ }^{11}$ and level of wage bargaining ( 1 dummy). ${ }^{12}$

\footnotetext{
${ }^{9}$ Our data set does not provide the firm age directly, which is why we proxied this variable with the seniority of the firm's most senior employee.

${ }^{10}$ As highlighted in section 4, information on firm size is taken from the 'Structure of Earnings Survey', while the value added per worker variable is constructed from the 'Structure of Business Survey'. This design
} 
i) $\gamma_{j, t}$ is a set of year dummies (7 dummies).

j) $v_{j, t}$ is the error term.

Equation (1) describes the relationship between average years of over-, required and under-education within firms and the productivity of the latter, when controlling for year dummies and mean worker and firm characteristics. ${ }^{13}$ The inclusion of the lagged dependent variable among the regressors accounts for the potential state dependence of firm productivity and aims to improve the identification of the parameters of interest in our preferred specification, i.e. system GMM (see discussion below). Equation (1) has been estimated with three different methods. The baseline regression relies on the pooled Ordinary Least Squares (OLS) estimator with standard errors robust to heteroscedasticity and serial correlation. This estimator is based on both the cross-section variability between firms and the longitudinal variability within firms over time.

Pooled OLS estimators of value added models have been criticized for their potential “heterogeneity bias” (Aubert and Crépon, 2003, p. 116). This bias is due to the fact that firm’s productivity depends to a large extent on firm-specific, time-invariant characteristics that are not measured in micro-level surveys. As a consequence, the OLS regression coefficients

eliminates the spurious relation issue that might have arisen due to common measurement error, i.e. because the number of employees appears on both sides of equation (1).

${ }^{11}$ Hourly residual wage dispersion after controlling for human capital variables and workers' characteristics in a wage equation following the Winter-Ebmer and Zweimüller (1999) methodology (i.e. standard deviations of residuals of wage regressions run for each firm and each year separately). This variable is controlled for because a growing literature highlights the productivity effects of wage inequality within firms. Yet, there is no theoretical consensus on the characteristics of this relationship. The "tournament model" proposed by Lazear and Rosen (1981) for instance stresses that a more differentiated wage structure stimulates workers' effort, through the incentive resulting from awarding the largest prize to the most productive worker. Their approach further suggests that the higher the pay spread, the higher the workers' optimal level of effort. In contrast, other theories argue that wage compression, i.e. a lower dispersion, reinforces workers' productivity by either improving labour relations (Akerlof and Yellen, 1988), sustaining and stimulating cohesiveness among the workforce (Levine, 1991) or preventing workers from engaging in costly rent-seeking activities instead of productive work (Milgrom and Roberts, 1990). Given the importance of this issue, a growing empirical literature is devoted to analysing the relationship between wage dispersion and firm performance (e.g. Hibbs and Locking, 2000, Heyman, 2005, Martins, 2008). However, the precise impact of wage dispersion on firm performance still remains unclear as both positive and negative impacts are suggested (for a review see Mahy et al. (2011a)).

12 Unfortunately, our data provide no direct information on firms' capital stock. However, van Ours and Stoeldraijer (2011) argue that the omission of the exact capital stock does not affect the estimates of production functions on firm-level data since the corresponding productivity effects tend to be small. This conclusion is in line with the results from the meta-analysis performed by Doucouliagos and Laroche (2003). It is also worthwhile to mention that the control variables in our specification are very similar to those used in recent papers examining the impact of demographics and pay systems on firm productivity (see e.g. Dostie, 2011, Grund and Westergaard-Nielsen, 2008, Göbel and Zwick, 2012).

13 Note that: $\left(\frac{1}{m_{j, t}} \sum_{i=1}^{m_{j, t}} R E Q_{i, j, t}+\frac{1}{m_{j, t}} \sum_{i=1}^{m_{j, t}} \operatorname{OVER}_{i, j, t}+\frac{1}{m_{j, t}} \sum_{i=1}^{m_{j, t}} \operatorname{UNDER}_{i, j, t}\right)=\frac{1}{m_{j, t}} \sum_{i=1}^{m_{j, t}}$ Attained $_{i, j, t}$, i.e. the sum of the average years of required, over-, and under-education in firm $j$ at time $t$ is equal to the average years of education attained by the workers employed in firm $j$ at time $t$. 
associated to ORU variables are likely to be biased since unobserved firm characteristics may affect simultaneously the firm's level of value added and its workforce average level of educational mismatch. This is referred to as a problem of spurious correlation and could be caused by factors such as an advantageous location, firm-specific assets like the ownership of a patent or other firm idiosyncrasies. To account for the unobserved time-invariant heterogeneity of firms, we re-estimated equation (1) with a fixed effects estimator (and standard errors that are robust to heteroscedasticity and serial correlation within firms (Huber/White/sandwich estimate of variance)). A fixed effects model does not estimate the level of productivity of firm $i$, but the change in productivity. Time-invariant heterogeneity is by definition not linked to changes in productivity and therefore controlled for.

An additional problem to address is the potential simultaneity between firm productivity and educational mismatch. As highlighted by Gautier et al. (2002, p. 523), “employers might exploit cyclical downturns to improve the average skill level of their work force”. To put it differently, there might be some cyclical 'crowding out', namely a process by which during recessions - because of excess labour supply - highly educated workers take the jobs that could be occupied by less educated ones. This assumption, supported empirically for certain countries including Belgium (Cockx and Dejemeppe, 2002, Dolado et al., 2000, Teulings and Koopmanschap, 1989), suggests that mean years of over-education within firms may increase as a result of a lower labour productivity (and vice versa). To control for this endogeneity issue, in addition to state dependence of firm productivity and the presence of firm fixed effects, we estimate equation (1) using the dynamic system Generalized Method of Moments (GMM) estimator proposed by Arellano and Bover (1995) and Blundell and Bond (1998).

This approach is standard in the literature regarding the productivity effects of labour heterogeneity (Göbel and Zwick, 2012, van Ours and Stoeldraijer, 2011). It boils down to estimate a system of two equations (one in level and one in first differences) simultaneously and to rely on 'internal instruments' to control for endogeneity. More precisely, ORU variables $^{14}$ in the differenced equation are instrumented by their lagged levels and ORU variables in the level equation are instrumented by their lagged differences. The implicit assumption is that changes (the level) in (of) productivity in one period, although possibly correlated with contemporaneous variations (levels) in (of) ORU variables, are (is) uncorrelated with lagged levels (differences) of the latter. Moreover, changes (levels) in (of) ORU variables are assumed to be reasonably correlated to their past levels (changes). One

\footnotetext{
${ }^{14} \mathrm{By}$ 'ORU variables', we mean ORU variables and other endogenous input factors.
} 
advantage of system GMM is that time-invariant explanatory variables can be included among the regressors, while the latter typically disappear in difference GMM. Asymptotically, the inclusion of these variables does not affect the estimates of the other regressors because instruments in the level equation (i.e. lagged differences of ORU variables) are expected to be orthogonal to all time-invariant variables (Roodman, 2009).

In order to find the correctly specified model, we start with the moment conditions that require less assumptions and increase the number of instruments progressively (Göbel and Zwick, 2012). To examine the validity of additional instruments, we apply the Hansen (1982) test of over-identifying restrictions. In addition, Arellano-Bond's (1991) test for serial correlation (i.e. for second-order autocorrelation in the first differenced errors) is used to assess whether estimates are reliable. Practically, to maximize sample size, we choose the model with minimum number of lags that pass the Hansen and Arellano-Bond's tests.

The adoption of a dynamic specification is likely to improve the identification of the parameters of interest (even though the coefficient on the lagged dependent variable is not a central issue of the analysis). Indeed, as illustrated by Bond (2002), the use of a dynamic model is necessary to obtain consistent results when estimating a production function with serially correlated productivity shocks and explanatory variables that are correlated to these shocks. While serial correlation of productivity shocks may arise if e.g. "the effects from demand shocks are only partially captured by the industry-specific control variables" (Hempell, 2005), the responsiveness of input factors to productivity shocks may be explained by the above mentioned endogeneity issue. Interestingly, the inclusion of the lagged dependent variable in the OLS, fixed effects and system GMM specifications also provides an ad hoc test for the appropriateness of the latter. As outlined by Roodman (2009), this test consists in checking whether the regression coefficient on the lagged dependent variable obtained with system GMM falls between the OLS and fixed effects estimates.

In addition to pooled OLS, fixed effects and dynamic system GMM estimations, we carried out several robustness tests. More precisely, we examined the sensitivity of our results to alternative measures of over-, required and under-education that control for the age cohort of workers. We also investigated whether the effects of educational mismatch on firm productivity vary according to the age of over- and under-educated workers. ${ }^{15}$

\footnotetext{
${ }^{15}$ In contrast to firms, workers cannot be followed over time in our data set. Hence, we are able to control for firms' but not for workers' fixed unobserved heterogeneity. Although workers' fixed effects are quantitatively important, recent papers suggest that the impact of educational mismatch on labour market outcomes is significant once the latter have been accounted for (Lamo and Messina, 2010, McGuinness and Sloane, 2011).
} 


\section{Data set and descriptive statistics}

Our empirical analysis is based on a combination of two large data sets covering the years 1999-2006. The first, carried out by Statistics Belgium, is the 'Structure of Earnings Survey' (SES). It covers all firms operating in Belgium that employ at least 10 workers and with economic activities within sections $\mathrm{C}$ to $\mathrm{K}$ of the NACE Rev. 1 nomenclature. ${ }^{16}$ The survey contains a wealth of information, provided by the management of firms, both on the characteristics of the latter (e.g. sector of activity, number of workers, level of collective wage bargaining) and on the individuals working there (e.g. age, education, tenure, gross earnings, paid hours, sex, occupation). ${ }^{17}$ The SES provides no financial information. Therefore, it has been merged with a firm-level survey, the 'Structure of Business Survey' (SBS). The SBS, also conducted by Statistics Belgium, provides information on financial variables such as firm-level value added and gross operating surplus per worker. The coverage of the SBS differs from that of the SES in that it does not cover the whole financial sector (NACE J) but only Other Financial Intermediation (NACE 652) and Activities Auxiliary to Financial Intermediation (NACE 67). The merger of the SES and SBS datasets has been carried out by Statistics Belgium using firms’ social security numbers.

A first point to consider for the econometric specification is that information in the SES refers to the month of October in each year, while data in the SBS are measured over entire calendar years, that is, over all months from January to December of each year. Hence, to

\footnotetext{
${ }^{16}$ It thus covers the following sectors: i) mining and quarrying (C), ii) manufacturing (D), iii) electricity, gas and water supply (E), iv) construction (F), v) wholesale and retail trade, repair of motor vehicles, motorcycles and personal and household goods $(\mathrm{G})$, vi) hotels and restaurants $(\mathrm{H})$, vii) transport, storage and communication (I), viii) financial intermediation $(\mathrm{J})$, and ix) real estate, renting and business activities $(\mathrm{K})$.

17 The SES is a stratified sample. The stratification criteria refer respectively to the region (NUTS-groups), the principal economic activity (NACE-groups) and the size of the firm. The sample size in each stratum depends on the size of the firm. Sampling percentages of firms are respectively equal to 10,50 and 100 percent when the number of workers is lower than 50, between 50 and 99, and above 100. Within a firm, sampling percentages of employees also depend on size. Sampling percentages of employees reach respectively 100, 50, 25, 14.3 and 10 percent when the number of workers is lower than 20, between 20 and 50, between 50 and 99, between 100 and 199, and between 200 and 299. Firms employing 300 workers or more have to report information for an absolute number of employees. This number ranges between 30 (for firms with between 300 and 349 workers) and 200 (for firms with 12,000 workers or more). To guarantee that firms report information on a representative sample of their workers, they are asked to follow a specific procedure. First, they have to rank their employees in alphabetical order. Next, Statistics Belgium gives them a random letter (e.g. the letter O) from which they have to start when reporting information on their employees (following the alphabetical order of workers' names in their list). If they reach the letter $\mathrm{Z}$ and still have to provide information on some of their employees, they have to continue from the letter A in their list. Moreover, firms that employ different categories of workers, namely managers, blue- and/or white-collar workers, have to set up a separate alphabetical list for each of these categories and to report information on a number of workers in these different groups that is proportional to their share in total firm employment. For example, a firm with 300 employees (namely, 60 managers, 180 white-collar workers and 60 blue-collar workers) will have to report information on 30 workers (namely, 6 managers, 18 white-collar workers and 6 blue-collar workers). For more details see Demunter (2000).
} 
avoid running a regression where information on the dependent variable precedes (to a large extent) the date on which the explanatory variables have been recorded, all explanatory variables in equation (1), except the lagged dependent variable, have been lagged by one year. In this way, information on educational mismatch relative to the month of October in year $t$ is used to explain firm-level productivity in year $t+1$. This methodological choice (and the use of a dynamic model) restricts our sample to firms that are observed in at least two consecutive years. Moreover, it leads to the over-representation of medium-sized and large firms given that sampling percentages of firms in our data set increase with the size of the latter (see footnote 17). Next, we exclude workers and firms for which data are missing or inaccurate. ${ }^{18}$ In order to guarantee that the required education is computed on a reasonable number of data points, we also eliminate occupations at the ISCO three-digit level with less than 10 observations. ${ }^{19}$ Finally, we drop firms with less than 10 observations, the reason for this being our use of average values at the firm level as control variables. ${ }^{20}$

Our final sample consists of an unbalanced panel of 8,954 firm-year-observations from 3,062 firms. It is representative of all medium-sized and large firms in the Belgian private sector, with the exception of large parts of the financial sector (NACE J) and the electricity, gas and water supply industry (NACE E).

\section{[Insert Table 1]}

Table 1 depicts the means and standard deviations of selected variables. It indicates that the mean number of required years of education at the firm-level is equal to $11.77 .^{21}$ The corresponding proportion of over- and under-educated workers within firms stands respectively at around 23 and 28 percent. Put differently, the average years of over- and under-education within firms are respectively equal to 0.59 and -0.93 . Moreover, we find that the average annual value added per worker is approximately equal to 89,800 EUR, around 27 percent of the workers within firms are women, 55 percent are blue collar, 76 percent are prime-age workers (i.e. between 30 and 49 years old), 38 percent have at least 10 years of tenure and 16 percent are part-timers (i.e. work less than 30 hours per week). On average,

\footnotetext{
${ }^{18}$ For instance, we eliminate a (very small) number of firms for which the recorded value added was negative.

${ }^{19}$ We did some robustness tests by fixing the threshold respectively at 30, 50 and 80 observations. However, given that the number of data points per occupation at the ISCO three-digit level is quite large, these alternative thresholds have little effect on sample size and leave results (available on request) unaffected.

${ }^{20}$ This restriction is unlikely to affect our results as it leads to a very small drop in sample size.

${ }^{21}$ The average value of the mean required education within firms has increased from 11.28 to 12.23 years between 1999 and 2006. In contrast, the standard deviation of the mean required education has no particular trend. It fluctuates between 0.99 and 1.41 over the period 1999-2006.
} 
firms employ 253 workers and they are essentially concentrated in the manufacturing sector (56 per cent), wholesale and retail trade, repair of motor vehicles, motorcycles and personal and household goods (12 percent), real estate, renting and business activities (12 percent), construction (9 percent) and transport, storage and communication (7 percent).

\section{Results}

\subsection{Benchmark specification}

We first estimated equation (1) by pooled OLS with standard errors that are robust to heteroscedasticity and serial correlation. As highlighted in section 4, explanatory variables have been lagged by one year to make sure that information on productivity does not precede information on educational mismatch. Results presented in the second column of Table 2 show that lagged productivity has a significant and positive impact on its contemporaneous value. Moreover, we find that an additional year of (average) required education within a firm has a positive and significant effect on firm productivity. The regression coefficient associated to required years education is equal to 0.017. This coefficient suggests that when the required level of education in a firm increases by one year ${ }^{22}$, the firm's productivity rises by $1.7 \%$ on average the year after. Regarding educational mismatch, we find that mean years of over-education exert a significant positive influence on firm productivity, while the reverse result is found for mean years of under-education. ${ }^{23}$ Indeed, results indicate that firm's productivity rises (decreases) on average by 1.6\% (0.9\%) following a one unit increase in mean years of over-education (under-education) the year before. ${ }^{24}$

However, these results suffer from the fact that time-invariant unobserved workplace characteristics are not accounted for. Therefore, we re-estimated equation (1) with a fixed effects estimator. Results, presented in the third column of Table 2, show again that productivity depends significantly and positively on its lagged value. However, the

\footnotetext{
${ }^{22}$ This may be the result of a change in: i) the occupational structure of the labour force within a firm, and/or ii) the occupational distribution of education across the entire economy.

${ }^{23}$ By definition, mean years of under-education take negative values in our data set (see equation (1), Table 1 and Appendix 1). Therefore, a positive regression coefficient should be interpreted as follows: when mean years of under-education increase (decrease), i.e. become less (more) negative, productivity rises (drops).

${ }^{24}$ The estimated parameters of our control variables (available upon request) are generally significant and correspond to the results reported in the literature. For instance, in line with Cataldi et al. (2011) or Göbel and Zwick (2012), they support the existence of a positive and hump-shaped relationship between workforce age and productivity. Moreover, as in Heyman (2005) or Mahy et al. (2011a,b), they show that intra-firm wage inequality stimulates firm performance. Yet, due to limited space, we do not discuss these results in greater detail.
} 
corresponding elasticity drops from 0.819 to 0.152 after controlling for fixed effects. As regards the estimate for the required level of education, it decreases from 0.017 to 0.008 and becomes statistically insignificant $(p$-value $=0.13)$. Coefficients on mean years of over- and under-education also turn out to be statistically insignificant when controlling for firm-level time-invariant heterogeneity.

Yet, these estimates are still inconsistent due to the endogeneity of ORU variables. To account for this issue (but also for state dependence of productivity and firm fixed effects), we re-estimate equation (1) using the dynamic system GMM estimator proposed by Arellano and Bover (1995) and Blundell and Bond (1998). Variables in the differenced equation are thus instrumented by their lagged levels and variables in the level equation are instrumented by their lagged differences. Time dummies are considered as exogenous and we use first and second lags of other explanatory variables as instruments. Results are presented in the last column of Table 2. To examine their reliability, we first apply the Hansen (1982) test of overidentifying restrictions and Arellano-Bond's (1991) test for second-order autocorrelation in the first differenced errors. As shown in Table 2, they respectively do not reject the null hypothesis of valid instruments and of no autocorrelation. As expected, we also find that current productivity is to a significant and important extent related to its past value. Interestingly, the coefficient on the lagged dependent variable falls between the OLS and fixed effects estimates. As outlined by Roodman (2009), this result supports the appropriateness of our dynamic system GMM specification. The regression coefficient on the average required years of education within firms is now significant at the $1 \%$ level and equal to 0.024 . This value suggests that when the required level of education in a firm increases by one year, the following period the firm's productivity rises on average by 2.4 percent. Results regarding the productivity effects of educational mismatch are also somewhat different from those obtained with the fixed effects estimator. As in the OLS specification, they now indicate that over-education has a significant positive influence on firms’ value added. More precisely, they show that firm's productivity increases on average by 3.5\% following a one unit increase in mean years of over-education. The reverse result is found for under-education. However, the coefficient on this variable (equal to 0.012 ) is only significant at the $11 \%$ level. $^{25}$

\footnotetext{
${ }^{25}$ A standard $t$-test shows that the effects on productivity are not significantly different for an additional year of required and over-education $(t=-0.86)$
} 


\subsection{Controlling for the birth cohort of workers}

Although the results reported so far take into account a range of issues related to the measurement of productivity and required education, they could nevertheless be misleading given that our indicators of ORU do not control for the birth cohort of workers. Indeed, given that years of education have substantially increased over time and that labour market experience could be a substitute to formal education, it may be more appropriate to determine whether a worker is over- or under-educated by comparing his level of education with the mode of the education among workers of a similar generation employed in the same occupation. Put differently, given that education and workers' age (i.e. a proxy for labour market experience) are probably the best variables in our data set to evaluate skills, as a robustness test it is worth computing ORU variables for workers belonging to a similar age group (i.e. with similar experience).

Practically, we considered two age groups and fixed the threshold for young and older workers at 35 years. Next, we computed the required education separately for young and older workers and defined a worker as over-educated (under-educated) if his level of education is higher (lower) than that required for workers belonging to the same age group and occupation at the ISCO 3-dgit level. Finally, equation (1) has been re-formulated such that: i) the average of the years of required education in firm $j$ at time $t$ equals the employment weighted sum of the required years of education for all jobs occupied respectively by young and older workers in firm $j$ at time $t$, and ii) the average of the years of over-education (under-education) in firm $j$ at time $t$ corresponds to the sum of the years of over-education among young and older workers in firm $j$ at time $t$, divided by the total number of workers employed in firm $j$ at time $t^{26}$

This new specification has been estimated with the dynamic system GMM estimator, which controls for firm fixed effects, simultaneity issues and dynamics in adjustment process of firm productivity. Results are presented in the second column of Table $3 .^{27}$ To test their reliability, we applied the Hansen (1982) test of overidentifying restrictions and ArellanoBond's (1991) test for second-order autocorrelation in the first differenced errors. As shown in Table 3, they support the consistency of our estimates. We also find that current productivity is to a significant and important extent related to its past value. As regards ORU

\footnotetext{
${ }^{26}$ A more detailed description can be obtained from the authors.

${ }^{27}$ Descriptive statistics relative to the ORU variables that control for the birth cohort of workers are reported in Appendix 1.
} 
variables, results again show that: i) productivity depends positively and significantly on average required years of education within firms, ii) mean years of over-education have a significant positive effect on firms' value added ${ }^{28}$, and iii) mean years of under-education have a negative but insignificant effect ( $\mathrm{p}$-value $=0.11$ ) on firm productivity ${ }^{29}$. Also noteworthy is that the magnitude of the regression coefficients associated to the ORU variables are not very different from those obtained on the basis of equation (1). Overall, it thus appears that our conclusions regarding the impact of ORU variables on firm productivity remain unchanged after controlling for the birth cohort of workers.

\subsection{Results according to workers' age}

A complementary issue that deserves to be investigated is whether the effects of educational mismatch on firm productivity vary according to the age of over- and undereducated workers.

From a theoretical point of view, we may expect the relationship between educational mismatch and productivity to be more pronounced for younger workers given that our indicators of over- and under-education are more likely to represent a real mismatch in skills for new labour market entrants. Indeed, one could argue that older workers can more easily compensate their lack of formal schooling (that is their 'under-education') by additional work experience and training. Moreover, workers who do not possess the required education for their job and who are no able to catch up (through training and work experience) will probably have (or choose) to exercise a less demanding job (in the same company or elsewhere) as they get older. On the other hand, skills learned at school tend to depreciate and to become obsolete over time so that older workers are less likely to have skills in excess of those required for their job. A related point is that workers whose 'over-education' is really beneficial for firm productivity are more likely to get promoted and to exercise a job matching their skills as they grow older. Overall, these arguments suggest that older over- and under-educated workers are less likely to affect productivity than their younger counterparts.

However, these predictions may not be verified. Indeed, older under-educated workers could still exert a negative impact on firm productivity if labour market experience is an imperfect substitute to formal education and that undereducated workers who are not able to

\footnotetext{
${ }^{28}$ A standard $t$-test again indicates that the impact on productivity of required and over-education is not statistically different $(t=-0.78)$

${ }^{29}$ See footnote 23.
} 
catch up remain in their jobs. On the other hand, it is possible that over-educated workers have a higher level of competence all over their career. Over-educated workers could for instance persistently: i) be more creative and independent, ii) adapt easier to a changing environment, iii) learn new skills faster and iv) have more ability to perform complex tasks and to interact with colleagues than workers having just the required education for the job. As a result, the positive effect of over-education on firm productivity may not vanish as overeducated workers get older.

To test the impact of educational mismatch on productivity for young and older generations of workers, as shown in the online appendix, we included as explanatory variables in our benchmark equation (that does control for cohort effects) mean years of overand under-education respectively among young and older workers in each firm. Results obtained with the dynamic system GMM estimator are presented in the third column of Table 3. Statistical tests do not reject the null hypothesis of valid instruments and of no autocorrelation. Moreover, we find that lagged productivity has a significant positive impact on its current value. As regards ORU variables, results first show that when the required level of education in a firm increases by one year, the firm's productivity rises on average by $2.1 \%$ the year after. Secondly, they indicate that mean years of over-education - both among young and older workers - have a significant positive influence on the firm's value added. More precisely, firm's productivity is found to rise on average by respectively 3.1 and $2.7 \%$ following a one unit increase in mean years of over-education among young and older workers the year before. Finally, findings show that mean years of under-education among young workers are detrimental for firm productivity. ${ }^{30}$ Indeed, an increase of one year in the incidence of under-education among young workers is found to decrease productivity on average by $3.5 \%$ one year later. By contrast, results reveal that years of under-education among older workers have no significant productivity effects. ${ }^{31}$

Standard $t$-statistics indicate that the effect on productivity is not statistically different for an additional year of required and over-education (both among young and older

\footnotetext{
${ }^{30}$ See footnote 23.

${ }^{31}$ Verdugo and Verdugo (1989) have suggested to compute the required education for a job through the mean (instead of the mode) of the workers' attained educated within occupations. A worker is then defined as over- or under-educated if his level of education deviates at least by one standard deviation from the required level of education for his job. As a robustness test, we estimated our benchmark equation (controlling for cohort effects) using this alternative definition of over-, required and under-education. Results, based on the dynamic system GMM estimator (available on request) are very similar to those reported in Table 3. Yet, the coefficient on older over-educated workers now turns out to be insignificant. Given that the approach suggested by Verdugo and Verdugo (1989) has been (heavily) criticized in the economic literature (see e.g. Bauer, 2002; Leuven and Oosterbeek, 2011), we attach more importance to the results based on the mode of the education by occupation.
} 
workers). ${ }^{32}$ Combining this result with the stylized fact that over-educated workers earn ceteris paribus less (more) than those who have the same attained education (than those who are doing the same job) but are correctly matched (McGuinness, 2006), one might expect that firms hiring proportionally more over-educated workers will be more profitable. To examine this issue, we re-estimated our benchmark equation (controlling for cohort effects) with the dynamic system GMM estimator using as dependent variable firm profitability, i.e. the gross operating surplus per worker. This variable is equal to the difference between the firm's value added at factor costs and personnel expenses (including employee social security contributions) divided by the total number of workers employed in the firm. Results, presented in Appendix 2, show that lagged profitability has a significant positive impact on its current value. In contrast, over-, required and under-education variables are not found to have any significant effect on firm profitability (even when over- and under-education variables are split according to workers' age). Although caution is required due to possible measurement errors in profits, results do not seem to support the hypothesis that firm's profitability depends positively on mean years of over-education. Findings rather suggest that the positive impact of over-education on productivity is neutralized by a comparable upward effect on wages, so that in the end profits remain unchanged. Moreover, results appear compatible with the idea that the negative impact of young under-educated workers on firm productivity is counterbalanced by a wage penalty for those workers so that profits are unaffected.

\section{Discussion and conclusion}

This paper is a first attempt at measuring the direct impact of educational mismatch on firm productivity. It also adds to previous research by examining whether the consequences of educational mismatch on firm productivity vary according to the age of over- and undereducated workers. From a methodological point of view, we relied on an ORU (Over-, Required and Under-education) specification that has been aggregated at the level of the firm; we used as dependent variable the average firm-level value added per worker and we applied the dynamic system GMM estimator to representative linked employer-employee panel data for Belgium covering the years 1999-2006. We thus examined how mean years of over- and under-education (among young and older workers) within firms affect the productivity of the latter, conditional on mean years of required education.

\footnotetext{
${ }^{32}$ The coefficient on under-education among young workers is also not statistically different from that on required education $(t=-0.87)$.
} 
Controlling for simultaneity issues, time-invariant unobserved workplace characteristics, cohort effects and dynamics in the adjustment process of productivity, we find that: i) a higher level of required education exerts a significantly positive influence on firm productivity, ii) additional years of over-education (both among young and older workers) are beneficial for firm productivity, and iii) additional years of under-education (among young workers) are detrimental for firm productivity.

These results suggest that: i) over-educated workers are more productive all over their career due to additional skills and capabilities acquired through schooling, and ii) undereducated workers either succeed to compensate their lack of productivity by additional work experience and training or end up in less demanding jobs as they get older. Our results can also easily be reconciled with the literature on the wage effects of educational mismatch. Indeed, they tend to support the hypothesis that over-educated (young under-educated) workers earn more (less) than those who have just the required education for the job because they are more (less) productive than the latter. On the contrary, our results do not support the hypothesis that over-educated workers are less productive because of frustration and a lower degree of job satisfaction. We may not exclude that, for a given job, educational mismatch may lead to less job satisfaction and worse correlated workers' attitudes and behaviours. However, it appears that the net effect of over-education on productivity is significant and positive. This finding is not surprising given that: i) estimates of the satisfaction-performance correlation reach at most 30 percent (e.g. Judge et al., 2001), ii) the literature regarding the impact of ORU on job satisfaction provides mixed results (e.g. Büchel, 2002, Hersch, 1991, Tsang et al., 1991, Verhaest and Omey, 2006), and iii) educational mismatch is likely to affect productivity through other channels than job satisfaction (and correlated workers' attitudes and behaviours), e.g. following human capital or assignment theories (Becker, 1964, Sattinger, 1993), it could be argued that a lower degree of job satisfaction might be compensated by additional skills and capabilities acquired in school so that the net effect of over-education on productivity might be positive (as suggested by our results).

A better understanding of the influence of workers' fixed unobserved characteristics on productivity is an important question for future research. It would also be interesting to test the stability of our results using: i) ORU variables that are computed on the basis of job analysis or worker self-assessment approaches, or ii) panel data covering a larger number of years. Yet, at the moment these robustness tests cannot be performed for the Belgian economy given data limitations. 


\section{Acknowledgements}

We are most grateful to Statistics Belgium for giving access to the data. We also would like to thank Mahmood Araï, Philip du Caju, Fredrik Heyman, Kostas Mavromaras, Seamus McGuiness, Peter Sloane and Ilan Tojerow for useful comments on an earlier version of this paper. Funding for this research was provided by the Belgian Federal Government - SPP Politique scientifique, programme "Société et Avenir", Employment, wage discrimination and poverty, research contract TA/00/046/EDIPO. All remaining errors are the authors' responsibility.

\section{References}

Ahn, J., Moon, S., \& Lee, Y. (2001). Mismatch and job satisfaction of Korean workers. Paper presented at the 2001 joint conference of the Asian consumer and family economics association and the China consumer economics research association, July 4-6, 2001, Shijiazhuang, China.

Akerlof, G., \&Yellen, J. (1988). Fairness and unemployment. American Economic Review, Papers and Proceedings, 78 (2), 44-49.

Allen, J., \& van der Velden, R. (2001). Educational mismatches versus skill mismatches: effects on wages, job satisfaction, and on-the-job search. Oxford Economic Papers, 53 (3), 434-452.

Arellano, M., \& Bond, O. (1991). Some tests of specification for panel data: Monte Carlo evidence and an application to employment equations. Review of Economic Studies, 58 (2), 277-297.

Arellano, M., \& Bover, O. (1995). Another look at the instrumental variable estimation of error-components models. Journal of Econometrics, 68 (1), 29-51.

Battu, H., Belfield, C., \& Sloane, P. (2000). How well can we measure graduate overeducation and its effects? National Institute Economic Review, 171 (1), 82-93.

Battu, H., Seaman, P., \& Sloane, P. (1999). Overeducation, undereducation and the British labour market. Applied Economics, 31 (11), 1437-1453.

Bauer, T. (2002). Educational mismatch and wages: a panel analysis. Economics of Education Review, 21 (3), 221-229. 
Bayard, K., Hellerstein, J., Neumark, D., \& Troske K. (2003). New evidence on sex segregation and sex differences in wages from matched employer-employee data. Journal of Labor Economics, 21 (4), 887-922.

Becker, G. (1964). Human capital. New York, National Bureau of Economic Research.

Blanchflower, D., \& Bryson, A. (2010). The wage impact of trade unions in the UK public and private sectors. Economica, 77 (305), 92-109.

Blundell, R., \& Bond, S. (1998). Initial conditions and moment restrictions in dynamic panel data models. Journal of Econometrics, 87 (1), 115-143.

Bond, S. (2002). Dynamic panel data models: a guide to micro data methods and practice. Portuguese Economic Journal, 1 (2), 141-162.

Büchel, F. (2002). The effects of overeducation on productivity in Germany - the firms' viewpoint. Economics of Education Review, 21 (3), 263-275.

Büchel, F., \& Mertens, A. (2004). Overeducation, undereducation, and the theory of career mobility. Applied Economics, 36 (8), 803-816.

Cahuc, P., \& Zylberberg, A. (2004). Labor economics. Cambridge (Ma.), MIT Press.

Cataldi, A., Kampelmann, S., \& Rycx, F. (2011). Productivity-wage gaps among age groups: does the ICT environment matter? De Economist, 159 (2), 193-22.

Chevalier, A. (2003). Measuring over-education. Economica, 70 (279), 509-531.

Chevalier, A., Harmon, C., Walker, I., \& Zhu, Y. (2004). Does education raise productivity, or just reflect it? Economic Journal, 114 (499), F499-F517.

Cockx, B., \& Dejemeppe, M. (2002). Do the higher educated unemployed crowd out the lower educated ones in a competition for jobs? IZA Discussion Paper, 541.

Demunter, C. (2000). Structure and distribution of earnings survey: analysis 1995. Statistics Belgium Working Paper.

Dolado, J., Felgueroso, F., \& Jimeno, J. (2000). Youth labour markets in Spain: education, training, and crowding-out. European Economic Review, 44 (4-6), 943-956.

Dolton, P., \& Silles, M. (2008). The effects of over-education on earnings in the graduate labour market. Economics of Education Review, 27 (2), 125-139.

Dolton, P., \& Vignoles, A. (2000). The incidence and effects of overeducation in the U.K. graduate labour market. Economics of Education Review, 19 (2), 179-198.

Dostie, B. (2011). Wages, productivity and ageing. De Economist, 159 (2), 139-158.

Doucouliagos, C., \& Laroche, P. (2003). What do unions do to productivity? A meta-analysis. Industrial Relations, 42 (4), 650-691. 
du Caju, P., Rycx, F., \& Tojerow, I. (2011). Inter-industry wage differentials: how much does rent-sharing matter? The Manchester School, 79 (4), 691-717.

Duncan, G., \& Hoffman, S. (1981). The incidence and wage effects of overeducation. Economics of Education Review, 1 (1), 75-86.

Feldman, D., \& Turnley, W. (1995). Underemployment among recent business college graduates. Journal of Organizational Behavior, 16 (6), 691-706.

Freeman, R. (1976). The overeducated American. New York, Academic Press.

Frenette, M. (2004). The overqualified Canadian graduate: the role of the academic program in the incidence, persistence, and economics return to overqualification. Economics of Education Review, 23 (1), 29-45.

Gautier, P., van den Berg, G., van Ours, J., \& Ridder, G. (2002). Worker turnover at the firm level and crowding out of lower educated workers. European Economic Review, 46 (3), 523-538.

Göbel, C., \& Zwick, T. (2012). Age and productivity: sector differences. De Economist, 160 (1), 35-57.

Groot, W. (1996). The incidence of, and return to overeducation in the UK. Applied Economics, 28 (10), 1345-1350.

Groot, W., \& Maassen van den Brink, H. (2000). Overeducation in the labor market: a metaanalysis. Economics of Education Review, 19 (2), 149-158.

Groot, W., \& Oosterbeek, H. (1994). Earnings effects of different components of schooling: human capital versus screening. Review of Economics and Statistics, 76 (2), 317-321.

Grund, C., \& Westergaard-Nielsen, N. (2008). The dispersion of employees' wage increases and firm performance. Industrial and Labor Relations Review, 61 (4), 485-501.

Hansen, L. (1982). Large sample properties of generalized method of moments estimators. Econometrica, 50 (4), 1029-1054.

Hartog, J. (2000). Over-education and earnings: where are we, where should we go? Economics of Education Review, 19 (2), 131-147.

Hempell, T. (2005). What's spurious? What's real? Measuring the productivity impacts of ICT at the firm level. Empirical Economics, 30 (2), 427-464.

Hersch, J. (1991). Education mismatch and job mismatch. Review of Economics and Statistics, 73 (1), 140-144.

Heyman, F. (2005). Pay inequality and firm performance: evidence from matched employeremployee data. Applied Economics, 37 (11), 1313-1327. 
Hibbs, D., \& Locking, H. (2000). Wage dispersion and productive efficiency: evidence for Sweden. Journal of Labor Economics, 18 (4), 755-782.

Iaffaldano, M., \& Muchinsky, P. (1985). Job satisfaction and job performance: a metaanalysis. Psychological Bulletin, 97 (2), 251-273.

Judge, T., Thoresen, C., Bono, J., \& Patton, G. (2001). The job satisfaction - job performance relationship: a qualitative and quantitative review. Psychological Bulletin, 127 (3), 367407.

Kahn, L., \& Morrow, P. (1991). Objective and subjective underemployment relationships to job satisfaction. Journal of Business Research, 22 (3), 211-218.

King, W., \& Hautaluoma, J. (1987). Comparison of job satisfaction, life satisfaction, and performance of overeducated and other workers. Journal of Social Psychology, 127 (5), 421-433.

Korpi, T., \& Tahlin, M. (2009). Educational mismatch, wages, and the wage growth: overeducation in Sweden, 1974-2000. Labour Economics, 16 (2), 183-193.

Lamo, A., \& Messina, J. (2010). Formal education, mismatch and wages after transition: assessing the impact of unobserved heterogeneity using matching estimators. Economics of Education Review, 29 (6), 1086-1099.

Lazear, E., \& Rosen, S. (1981). Rank-order tournaments as optimum labor contracts. Journal of Political Economy, 89 (5), 841-864.

Levine, D. (1991). Cohesiveness, productivity and wage dispersion. Journal of Economic Behavior and Organization, 15 (2), 237-255.

Leuven, E., \& Oosterbeek, H. (2011). Overeducation and mismatch in the labor market. IZA Discussion Paper, 5523 (Bonn).

Mahy, B., Volral, M., \& Rycx, F. (2011a). Does wage dispersion make all firms productive? Scottish Journal of Political Economy, 58 (4), 455-489.

Mahy, B., Volral, M., \& Rycx, F. (2011b). Wage dispersion and firm productivity in different working environments. British Journal of Industrial Relations, 49 (3), 460-485.

Manning, A. (2003). Monopsony in motion. Imperfect competition in labor markets. , Princeton, Princeton University Press.

Martins, P. (2008). Dispersion in wage premiums and firm performance. Economics Letters, $101(1), 63-65$.

Martins, P. (2009). Rent sharing before and after the wage bill. Applied Economics, 41 (17), 2133-2151. 
McGuinness, S. (2003). Graduate overeducation as a sheepskin effect: evidence from Northern Ireland. Applied Economics, 35 (5), 597-608.

McGuinness, S. (2006). Overeducation in the labour market. Journal of Economic Surveys, 20 (3), 387-418.

McGuinness, S., \& Sloane, P. (2011). Labour market mismatch among UK graduates: an analysis using REFLEX data. Economics of Education Review, 30 (1), 130-145.

Milgrom, P., \& Roberts, J. (1990). The efficiency of equity in organisational decision processes. American Economic Review, Papers and Proceedings, 80 (2), 154-159.

Mortensen, D. (2003). Wage dispersion. Why are similar workers paid differently? Cambridge (Ma.), MIT Press.

OECD (2011). Employment outlook. Paris, OECD.

Riley, J. (2001). Silver signals: twenty-five years of screening and signaling. Journal of Eonomic Literature, 39 (2), 432-478.

Robst, J. (1995). Career mobility, job match, and overeducation. Eastern Economic Journal, 21 (4), 539-550.

Roodman, D. (2009). How to do xtabond2: an introduction to difference and system GMM in Stata. Stata Journal, 9 (1), 86-136.

Rumberger, R. (1987). The impact of surplus schooling on productivity and earnings. Journal of Human Resources, 22 (1), 24-50.

Rusinek, M., \& Rycx, F. (2012). Rent-sharing under different bargaining regimes: evidence from linked employer-employee data. British Journal of Industrial Relations, in press.

Sattinger, M. (1993). Assignment models of the distribution of earnings. Journal of Economic Literature, 31 (2), 831-880.

Sicherman, N. (1991). Overeducation in the labor market. Journal of Labor Economics, 9 (2), 101-122.

Sicherman, N., \& Galor, O., 1990. A theory of career mobility. Journal of Political Economy 98 (1), 169-192.

Spence, M. (1973). Job market signaling. Quarterly Journal of Economics, 87 (3), 355-374.

Spence, M (1979). Signalling, screening and information. In: S. Rosen, Studies in labor markets. Chicago: Chicago University Press.

Teulings, C., \& Koopmanschap, M. (1989). An econometric model of crowding out of lower education levels. European Economic Review, 33 (8), 1653-1664.

Thurow, L. (1975). Generating inequality. New York, Basic books. 
Tsang, M. (1987). The impact of underutilization of education on productivity: a case study of the U.S. Bell companies. Economics of Education Review, 6 (3), 239-254.

Tsang, C., Rumberger, R., \& Levin, H. (1991). The impact of surplus schooling on worker productivity. Industrial Relations, 30 (2), 209-228.

van der Meer, P. (2006). Two validity of two education requirement measures. Economics of Education Review, 25 (2), 211-219.

van Ours, J., \& Stoeldraijer, L. (2011). Age, wage and productivity in Dutch manufacturing. De Economist, 159 (2), 113-138.

van Smoorenburg, M., \& van der Velden, R. (2000). The training of school-leavers: complementary or substitution? Economics of Education Review, 19 (2), 207-217.

Verdugo, R., \& Verdugo, N. (1989). The impact of surplus schooling on earnings. Some additional findings. Journal of Human Resources, 24 (4), 629-643.

Verhaest, D., \& Omey, E. (2006). The impact of overeducation and its measurement. Social Indicators Research, 77 (3), 419-448.

Verhaest, D., \& Omey, E. (2009). Objective over-education and worker well-being: a shadow price approach. Journal of Economic Psychology, 30 (3), 469-481.

Verhofstadt, E., \& Omey, E. (2003). The impact of education on job satisfaction in the first job. FEB Working Paper, 169 (Ghent University).

Vieira, J. (2005). Skill mismatches and job satisfaction. Economics Letters, 89 (1), 39-47.

Winter-Ebmer, R., \& Zweimüller, J. (1999). Intra-firm wage dispersion and firm performance. Kyklos, 52 (4), 555-572. 
Table 1: Means and standard deviation of selected variables, 1999-2006

\begin{tabular}{|c|c|c|}
\hline Variables: & Mean & Std. Dev. \\
\hline Annual added value per worker $\left(€^{1}\right)$ & 89,788 & 649,572 \\
\hline Annual value added per worker (ln) & 11.07 & 0.61 \\
\hline Required education (years) & 11.77 & 1.35 \\
\hline \multicolumn{3}{|l|}{ Over-education: } \\
\hline Percentage workers & 22.53 & 23.28 \\
\hline Years & 0.59 & 0.65 \\
\hline \multicolumn{3}{|l|}{ Under-education: } \\
\hline Percentage workers & 27.60 & 26.53 \\
\hline Years & -0.93 & 1.01 \\
\hline Intra-firm wage dispersion $\left(€^{1,2}\right)$ : & 0.17 & 0.09 \\
\hline Workers with 10 years of tenure or more (\%) & 38.06 & 24.38 \\
\hline Women (\%) & 26.94 & 23.91 \\
\hline Share of workers $<30$ years & 8.10 & 8.74 \\
\hline Share of workers between 30 and 49 years & 75.69 & 12.59 \\
\hline Share of workers $>49$ years & 16.25 & 12.18 \\
\hline Blue-collar workers ${ }^{3}(\%)$ & 54.60 & 33.93 \\
\hline Part-time (less than 30 hours per week, \%) & 16.18 & 16.75 \\
\hline Size of the firm (number of workers) & 252.57 & 275.04 \\
\hline Firm-level collective agreement (\%) & 30.63 & 45.80 \\
\hline \multicolumn{3}{|l|}{ Sector $(\%)$ : } \\
\hline Mining and quarrying (C) & 0.70 & \\
\hline Manufacturing (D) & 56.10 & \\
\hline Electricity, gas and water supply (E) & 0.36 & \\
\hline Construction $(\mathrm{F})$ & 9.31 & \\
\hline $\begin{array}{l}\text { Wholesale and retail trade, repair of motor vehicles, motorcycles } \\
\text { and personal and household goods (G) }\end{array}$ & 12.26 & \\
\hline Hotels and restaurants $(\mathrm{H})$ & 1.69 & \\
\hline Transport, storage and communication (I) & 6.62 & \\
\hline Financial intermediation $(J)$ & 1.34 & \\
\hline Real estate, renting and business activities (K) & 11.62 & \\
\hline Number of observations & \multicolumn{2}{|c|}{8,954} \\
\hline Number of firms & \multicolumn{2}{|c|}{3,062} \\
\hline \multicolumn{3}{|c|}{$\begin{array}{l}{ }^{1} \text { At } 2006 \text { constant prices. }{ }^{2} \text { Hourly residual wage dispersion after controlling for human capital variables and } \\
\text { workers' characteristics in a wage equation following the Winter-Ebmer and Zweimüller (1999) methodology } \\
\text { (i.e. standard deviations of residuals of wage regressions run for each firm and each year separately). }{ }^{3} \text { The } \\
\text { distinction between blue- and white-collar workers is based on the International Standard Classification of } \\
\text { Occupations (ISCO-88). Workers belonging to groups } 1 \text { to } 5 \text { are considered to be white-collar workers (1: } \\
\text { Legislators, senior officials and managers; 2: Professionals; 3: Technicians and associate professionals; } 4 \text { : } \\
\text { Clerks; 5: Service workers and shop and market sales workers) and those from groups } 7 \text { to } 9 \text { are considered to be } \\
\text { blue-collar workers (7: Craft and related trades workers; 8: Plant and machine operators and assemblers; 9: } \\
\text { Elementary occupations). }\end{array}$} \\
\hline
\end{tabular}


Table 2: Educational mismatch and firm productivity

(OLS, Fixed-effects and GMM estimates, 1999-2006)

\begin{tabular}{|c|c|c|c|}
\hline \multirow[t]{2}{*}{ Dependent variable: } & \multicolumn{3}{|c|}{ Value-added per worker (In) } \\
\hline & $\begin{array}{l}(1) \\
\text { OLS }\end{array}$ & $\begin{array}{l}(2) \\
\text { FE }\end{array}$ & $\begin{array}{c}(3) \\
\text { GMM-SYS }^{5}\end{array}$ \\
\hline $\begin{array}{l}\text { Value-added per worker } \\
\text { (one year lagged, in ln) }\end{array}$ & $\begin{array}{c}0.819 * * * \\
(0.017)\end{array}$ & $\begin{array}{c}0.152^{* * *} \\
(0.030)\end{array}$ & $\begin{array}{c}0.553 * * * \\
(0.049)\end{array}$ \\
\hline $\begin{array}{l}\text { Required education } \\
\text { (one year lagged, in years) }\end{array}$ & $\begin{array}{c}0.017 * * * \\
(0.003)\end{array}$ & $\begin{array}{c}0.008 \\
(0.005)\end{array}$ & $\begin{array}{c}0.024 * * * \\
(0.008)\end{array}$ \\
\hline $\begin{array}{l}\text { Over-education } \\
\text { (one year lagged, in years) }\end{array}$ & $\begin{array}{c}0.016^{* * *} \\
(0.005)\end{array}$ & $\begin{array}{c}0.003 \\
(0.006)\end{array}$ & $\begin{array}{c}0.035^{* * *} \\
(0.010)\end{array}$ \\
\hline $\begin{array}{l}\text { Under-education }^{1} \\
\text { (one year lagged, in years) }\end{array}$ & $\begin{array}{l}0.009 * * \\
(0.006)\end{array}$ & $\begin{array}{l}-0.001 \\
(0.005)\end{array}$ & $\begin{array}{c}0.012 \\
(0.008)\end{array}$ \\
\hline Worker characteristics $^{2}$ : & Yes & Yes & Yes \\
\hline Firm characteristics ${ }^{3}$ : & Yes & Yes & Yes \\
\hline Year dummies (7): & Yes & Yes & Yes \\
\hline R-squared & 0.774 & & \\
\hline Within R-squared & & 0.043 & \\
\hline Sig. Model (p-value) & 0.000 & 0.000 & 0.00 \\
\hline $\begin{array}{l}\text { Hansen statistic } \\
\text { p-value }\end{array}$ & & & $\begin{array}{c}346.1 \\
0.21\end{array}$ \\
\hline $\begin{array}{l}\text { Arellano-Bond statistic (AR2) } \\
\text { p-value }\end{array}$ & & & $\begin{array}{l}1.36 \\
0.18\end{array}$ \\
\hline Number of observations & 8,954 & 8,954 & 8,954 \\
\hline Number of firms & 3,062 & 3,062 & 3,062 \\
\hline
\end{tabular}

Notes: $* * * * * / *$ significant at the 1, 5 and 10\% level, respectively. Robust standard errors are reported between brackets.

${ }^{1}$ By definition, mean years of under-education take negative values in our data set (see equation (1), Table 1 and Appendix 1).

Therefore, a positive regression coefficient should be interpreted as follows: when mean years of under-education increase (decrease),

i.e. become less (more) negative, productivity rises (drops).

${ }^{2}$ Share of the workforce that: i) has at least 10 years of tenure, and ii) is younger than 25 and older than 49 years, respectively. The share of women, blue-collar and part-time workers as well as the conditional dispersion in hourly wages are also included.

${ }^{3}$ Sectoral affiliation (8 dummies), number of workers, age of the firm and level of wage bargaining (1 dummy).

${ }^{4}$ AR2 displays the test for second-order autocorrelation in the first-differenced errors.

${ }^{5}$ First and second lags of explanatory variables, excluding time dummies, are used as instruments in the GMM specification. 
Table 3: Educational mismatch and firm productivity (GMM estimates, controlling for cohort effects, 1999-2006)

Dependent variable: Value-added per worker (In)

(1)

(2)

GMM-SYS
$0.553^{* * *}$
$(0.048)$
$0.023^{* * *}$
$(0.008)$
$0.033^{* * *}$
$(0.010)$
0.015
$(0.009)$

(one year lagged, in years)

GMM-SYS $^{5}$

Value-added per worker

(one year lagged, in ln)

$\mathrm{S}^{5}$

$0.557 * * *$

Required education

(one year lagged, in years)

(0.009)

Over-education

(one year lagged, in years)

Over-education among young workers

(one year lagged, in years)

Over-education among older workers

(one year lagged, in years)

Under-education among young workers ${ }^{1}$

(one year lagged, in years)

Under-education among older workers ${ }^{1}$

(one year lagged, in years)

Worker characteristics ${ }^{2}$ :

Yes

Yes

Firm characteristics ${ }^{3}$ :

Yes

Yes

Year dummies (7):

Yes

Yes

Sig. Model (p-value)

0.000

0.000

Hansen statistic

352.4

386.1

p-value

0.15

0.15

Arellano-Bond statistic (AR2) ${ }^{4}$

1.32

1.35

p-value

0.19

0.18

Number of observations

8,954

8,954

Number of firms

3,062

3,062

Notes: ***/**/* significant at the 1, 5 and 10\% level, respectively.

Robust standard errors are reported between brackets.

${ }^{1}$ By definition, mean years of under-education take negative values in our data set (see equation (1), Table 1 and Appendix 1). Therefore, a positive regression coefficient should be interpreted as follows: when mean years of under-education increase (decrease), i.e. become less (more) negative, productivity rises (drops).

${ }^{2}$ Share of the workforce that: i) has at least 10 years of tenure, and ii) is younger than 25 and older than 49 years, respectively. The share of women, blue-collar and part-time workers as well as the conditional dispersion in hourly wages are also included.

${ }^{3}$ Sectoral affiliation (8 dummies), number of workers, age of the firm and level of wage bargaining (1 dummy).

${ }^{4}$ AR2 displays the test for second-order autocorrelation in the first-differenced errors.

${ }^{5}$ First and second lags of explanatory variables, excluding time dummies, are used as instruments. 
Appendix 1: Means and standard deviations of over-, required and under-education variables when controlling for the age cohort of workers, 1999-2006

\begin{tabular}{|c|c|c|}
\hline Variables: & Mean & Std. Dev. \\
\hline Required education (years) & 11.54 & 1.37 \\
\hline \multicolumn{3}{|l|}{ Over-education: } \\
\hline \multicolumn{3}{|l|}{ Percentage } \\
\hline All worker & 24.87 & 22.46 \\
\hline Young workers & 8.33 & 11.78 \\
\hline Older workers & 16.54 & 16.65 \\
\hline \multicolumn{3}{|l|}{ Years } \\
\hline All worker & 0.67 & 0.64 \\
\hline Young workers & 0.21 & 0.32 \\
\hline Older workers & 0.45 & 0.49 \\
\hline \multicolumn{3}{|l|}{ Under-education: } \\
\hline \multicolumn{3}{|l|}{ Percentage } \\
\hline All worker & 24.17 & 23.21 \\
\hline Young workers & 9.86 & 12.93 \\
\hline Older workers & 14.31 & 16.81 \\
\hline \multicolumn{3}{|l|}{ Years } \\
\hline All worker & -0.78 & 0.87 \\
\hline Young workers & -0.31 & 0.46 \\
\hline Older workers & -0.47 & 0.62 \\
\hline Number of observations & \multicolumn{2}{|c|}{8,954} \\
\hline Number of firms & \multicolumn{2}{|c|}{3,062} \\
\hline
\end{tabular}




\section{Appendix 2: Educational mismatch and firm profitability (GMM estimates, controlling for cohort effects, 1999-2006)}

\begin{tabular}{|c|c|c|}
\hline \multirow[t]{2}{*}{ Dependent variable: } & \multicolumn{2}{|c|}{ Gross operating surplus per worker (ln) } \\
\hline & $\stackrel{(1)}{\text { GMM-SYS }^{5}}$ & $\begin{array}{c}(2) \\
\text { GMM-SYS }^{5}\end{array}$ \\
\hline $\begin{array}{l}\text { Gross operating surplus per worker } \\
\text { (one year lagged, in ln) }\end{array}$ & $\begin{array}{l}0.361^{* * *} \\
(0.087)\end{array}$ & $\begin{array}{c}0.386 * * * \\
(0.083)\end{array}$ \\
\hline $\begin{array}{l}\text { Required education } \\
\text { (one year lagged, in years) }\end{array}$ & $\begin{array}{l}-0.019 \\
(0.059)\end{array}$ & $\begin{array}{c}0.001 \\
(0.056)\end{array}$ \\
\hline $\begin{array}{l}\text { Over-education } \\
\text { (one year lagged, in years) }\end{array}$ & $\begin{array}{c}0.079 \\
(0.097)\end{array}$ & \\
\hline $\begin{array}{l}\text { Under-education }^{1} \\
\text { (one year lagged, in years) }\end{array}$ & $\begin{array}{c}0.050 \\
(0.068)\end{array}$ & \\
\hline $\begin{array}{l}\text { Over-education among young workers } \\
\text { (one year lagged, in years) }\end{array}$ & & $\begin{array}{c}0.206 \\
(0.146)\end{array}$ \\
\hline $\begin{array}{l}\text { Over-education among older workers } \\
\text { (one year lagged, in years) }\end{array}$ & & $\begin{array}{c}0.013 \\
(0.108)\end{array}$ \\
\hline $\begin{array}{l}\text { Under-education among young workers }{ }^{1} \\
\text { (one year lagged, in years) }\end{array}$ & & $\begin{array}{c}0.067 \\
(0.106)\end{array}$ \\
\hline $\begin{array}{l}\text { Under-education among older workers }{ }^{1} \\
\text { (one year lagged, in years) }\end{array}$ & & $\begin{array}{c}0.039 \\
(0.090)\end{array}$ \\
\hline Worker characteristics ${ }^{2}$ : & Yes & Yes \\
\hline Firm characteristics ${ }^{3}:$ & Yes & Yes \\
\hline Year dummies (7): & Yes & Yes \\
\hline Sig. Model (p-value) & 0.000 & 0.00 \\
\hline Hansen statistic & 243.2 & 262.0 \\
\hline p-value & 0.38 & 0.40 \\
\hline Arellano-Bond statistic (AR2) ${ }^{4}$ & 1.34 & 1.61 \\
\hline p-value & 0.18 & 0.11 \\
\hline Number of observations & 7,720 & 7,720 \\
\hline Number of firms & 2,813 & 2,813 \\
\hline
\end{tabular}

Notes: $* * * / * * / *$ significant at the 1,5 and $10 \%$ level, respectively.

Robust standard errors are reported between brackets.

${ }^{1}$ By definition, mean years of under-education take negative values in our data set (see equation (1),

Table 1 and Appendix 1). Therefore, a positive regression coefficient should be interpreted as follows: when mean years of under-education increase (decrease), i.e. become less (more) negative, profitability rises (drops).

${ }^{2}$ Share of the workforce that: i) has at least 10 years of tenure, and ii) is younger than 25 and older than 49 years, respectively. The share of women, blue-collar and part-time workers as well as the conditional dispersion in hourly wages are also included.

${ }^{3}$ Sectoral affiliation (8 dummies), number of workers, age of the firm and level of wage bargaining (1 dummy).

${ }^{4}$ AR2 displays the test for second-order autocorrelation in the first-differenced errors.

${ }^{5}$ First and second lags of explanatory variables, excluding time dummies, are used as instruments. 